\title{
Identification Of THE Degree of Polarization OF Districts NUTS4 IN THE LoWer Silesian Province With the USE OF Measure OF DEVELOPMENT
}

\author{
Marta Zarówna ${ }^{1}$; Dagmara Dyrda ${ }^{2}$ \\ Wroclaw University of Economics, Faculty of Economics, Management and Tourism, \\ ${ }^{1}$ Department of Regional Economy, \\ ${ }^{2}$ Department of Quality and Environmental Management, \\ ul. Nowowiejska 3, 58-500 Jelenia Góra, Poland \\ e-mail: ${ }^{1}$ kaliszak@gmail.com; ${ }^{2}$ dagmara.dyrda1987@gmail.com
}

\begin{abstract}
Identification and study of regional development disparities are of great importance from the point of view of the effectiveness of actions undertaken within the framework of regional policy. The purpose of this article is to determine the degree of polarization of districts in the Lower Silesia and the division into groups based on the levels of development in the years 2003, 2008, 2013. The first chapter gives an overview of the theory of polarization and a review of existing studies. The next chapter describes in detail the objectives and research areas. The third chapter is dedicated to the research methodology with a particular emphasis on the synthetic measure of economic development. The final section presents the results of the tests.
\end{abstract}

\section{Introduction}

The problem of polarization of development is very significant from the point of view of setting targets and the effectiveness of actions undertaken within the framework of regional policy. An expression of this in the Polish regional policy is represented by the final recommendations of the Report Poland 2030, which pointed out the requirement to implement a polarization and diffusion model. The report envisages the initiation of boosting the development of the biggest Polish agglomerations and the gradual elimination of barriers to participation in this process for a larger group of regions [1]. The issue has become the subject of many research papers, the review of which is presented in the following chapter. This study is intended to fill the research gap at the lower levels of regional decentralization. The research problem is an attempt to answer the question: how big is the extent of polarization between the districts of the province of Lower Silesia and whether it changes over time?

\section{The outline of the theory of polarization and a review of research}

The problem of disparities in regional development is the root of all regional development theory in economics. It has begun with A. Smith and his most influential work: An Inquiry into the Nature and Causes of the Wealth of Nations [2]. In the context of inter-regional disparities, the mostly used issue in the literature is the dichotomy between theories of sustainable development and unsustainable development. In the first case, the disparities are considered as interference. The natural state of economy is an equilibrium and striving to achieve it. Unsustainable development theories emphasize the existence of imbalances as the driving force of development. Disparities are a natural and unavoidable result of the natural characteristics of socio-economic development [3]. The general theory of polarization should include an explanation of the mechanism of formation of the dynamic growth areas and the 
extent of the impact on the surrounding areas [4]. F. Perroux and A. O. Hirschman have been considered the forerunners of the growth poles and trickle down paradigm, which had been the basis for the development of the growth center approach. It is based on the assertion that "development can start only in a relatively few dynamic sectors and geographic locations from where it is expected to spread to the remaining sectors and geographical areas of a country." [5] In the design of the concept of F. Perroux, the impact of growth poles has been associated with economic space (sectoral polarization). This approach was quickly transposed to the geographical space in the works of G. Myrdal, A. O. Hirschman, and J. Friedman (spatial polarization). The appearance of these approaches has significantly shaped regional development thinking. This was particularly relevant for the reorientation of the regional policy. Inequalities began to be seen as an opportunity, rather than as a threat. Changing the approach has forced a more in-depth identification of the level of socio-economic development of the regions in the context of the degree of their mutual polarization. There are many studies of regional development disparities at the national level based on the HDI (Human Development Index), socio-economic indicators, the weighted mathematical methods. The studies of disparities, including lower levels of administrative divisions (NUTS3, NUTS4) have been conducted in the world by inter alia, C. Riskin [6], L. Fedorov [7], J. Vanderpnye-Orgle [8]. C. Riskin observed differences in the development between the provinces of China in 1950s, in terms of industrialization. L. Fedorov analyzed the impact of the transition period on regional disparities in Russia in the 1990s. J. Vanderpnye-Orgle examined the growing trends in spatial inequalities and polarization in Ghana during the period of stabilization and structural adjustment programmes in the 1980s and 1990s. The results of these studies indicate that inequality increases during the first period of reforms, and in subsequent years, a gradual convergence begins. In Poland, studies on this subject were conducted by M. Musiał-Malago [9], K. Wawrzyniak, B. Batóg [10]. The subject of M. Musiał-Malago's concern was the structural polarization research methods on the example of the Krakow Metropolitan Area. K. Wawrzyniak and B. Batóg analyzed the polarization of districts of the West Pomeranian divided into the areas of demographics, urbanization, structural and labour market. The study used the measure of Bray-Curtis to calculate the distance of each area from the center of growth (Stettin).

\section{Objectives and areas of research}

The first objective of the study is to determine the degree of polarization of the districts of Lower Silesia in terms of most favourable standard of development. An ideal standard of development is an abstract entity, for which all variables take the best value in terms of view of criterion of the purpose. In this paper, the polarity is defined as the persistence of advantage of expansive centers [11]. The degree of polarization is understood as the difference between the values of development measure of growth centers and values of development measures in other regions.

The second aim of the study is the division of research objects into similar classes in terms of the level of socio-economic development. This will allow the identification of the most developed areas and the most backward ones.

The survey covered 29 districts of the province of Lower Silesia qualified in accordance with the Nomenclature of Territorial Units for Statistics at level 4. In order to ensure comparability of the data, Wałbrzych was not included in the study because there was a change of qualifications in NUTS4 in the analyzed period. The study was conducted on the basis of 13 variables divided into 4 areas of polarization. The areas of polarization and indicators have been selected in accordance with the guidelines contained in the work of A. Malina [12]. The main limitation of the selection of variables for this study was the availability of the data at 
the level of NUTS4. Selection of variables by dimensions of polarization is presented in Table 1.

The data for this study consist of observations from the Local Data Bank of Polish Central Statistical Office (GUS). Due to the data availability the study covered the years 2003, 2008 and 2013.

Tab. 1: Variables and dimensions of polarization

\begin{tabular}{|c|c|c|}
\hline $\begin{array}{l}\text { Dimensions of } \\
\text { polarization }\end{array}$ & Variables & Source \\
\hline \multirow[t]{3}{*}{ Social dimension } & $x_{1}$ - average usable floor space for 1 person & \multirow{3}{*}{ 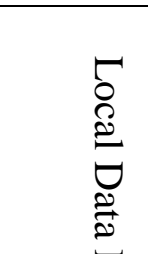 } \\
\hline & $x_{2}$ - registered unemployment rate & \\
\hline & $\begin{array}{l}x_{3}-\text { average monthly salary in relation to the national } \\
\text { average. }\end{array}$ & \\
\hline \multirow{5}{*}{$\begin{array}{l}\text { Economic } \\
\text { dimension }\end{array}$} & $x_{4}$ - investment outlays in enterprises per capita & \multirow{5}{*}{ 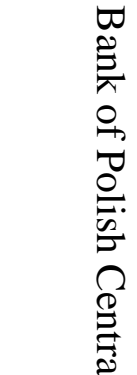 } \\
\hline & $x_{5}-$ gross value of fixed assets in enterprises per capita & \\
\hline & $x_{6}$ - entities per 1,000 population in the working age & \\
\hline & $\begin{array}{l}x_{7}-\text { newly registered entities per } 10 \text { thousand working-age } \\
\text { population }\end{array}$ & \\
\hline & $x_{8}$ - flats put into use per 10 thousand inhabitants & \\
\hline \multirow{3}{*}{$\begin{array}{l}\text { Urbanization and } \\
\text { infrastructural } \\
\text { dimension }\end{array}$} & $x_{9}-$ population per $1 \mathrm{~km} 2$ & \multirow{5}{*}{ 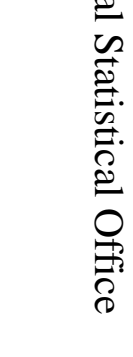 } \\
\hline & $x_{10}-$ municipal and county paved roads per $100 \mathrm{~km} 2$ & \\
\hline & $x_{11}$ - flats per 1,000 inhabitants & \\
\hline \multirow[t]{2}{*}{$\begin{array}{l}\text { Demographic } \\
\text { dimension }\end{array}$} & $\begin{array}{l}x_{12}-\text { population in retirement age as a percentage of the total } \\
\text { population }\end{array}$ & \\
\hline & $x_{13}$ - birth rate per 1,000 population & \\
\hline
\end{tabular}

Source: Own

\section{$3 \quad$ Methodology}

The survey was conducted using a multidimensional comparative analysis, which enables comparisons of objects defined by many diverse features. The aim of the methods of linear ordering is to arrange the objects from the best to the worst according to the accepted criterion. The methods of linear ordering include the development pattern methods [13]. The idea is based on the concept that the selected most favorable alternative should have the shortest distance from the development pattern and the farthest distance from the development anti-pattern in a geometrical sense. The development pattern is an abstract object with the best values of the adopted variables. A separate development pattern has been created for each of the years, and it contains the best values of variables for the given year.

The first stage of the study was to determine the character of the variables. The variables can be divided into stimulants (higher values of variables are more desirable), destimulants (lower values of variables are more desirable), and nominants (defined values of variables are desirable) [13]. Among the variables taken into consideration were the following destimulants: $x_{2}$ - registered unemployment rate, $x_{12}$ - population in retirement age as a percentage of the total population. Conversion to stimulants was performed using formula (1)

$$
S_{i j}=b\left[D_{i j}\right]^{-1},
$$


where

$S_{i j}$ is the value of the $j$-th variable after being changed to a stimulant in the $i$-th object,

$D_{i j}$ is the value of the $j$-th variable in the $i$-th object,

$b$ is the minimum value of $D_{i j}$

In the next step, the variables were standardized in accordance with formula (2)

$$
z_{i j}=\frac{x_{i j}-\overline{x_{j}}}{S_{j}},
$$

where

$z_{i j}$ is the standardized value of the $j$-th variable in the $i$-th object,

$\overline{x_{j}}$ is the arithmetic mean of the $j$-th variable,

$S j$ is the standard deviation of the $j$-th variable.

In the next step, the similarity of objects to the ideal object was examined by calculation of the distance of each object from the development pattern. As a measure of distance was used measure of the Euclidean. The lower distance from the development pattern defines a higher level of the complex phenomenon [13].

The next stage of research was the determination of the development measure for each object, using formula (3) from [13]:

$$
m_{i}=1-\frac{d_{i 0}}{d_{0}}, i=1,2, \ldots, n
$$

where

$m_{i}$ is the development measure for the $i$-th object,

$d_{i 0}$ distance of the $i$-th object from the pattern,

$d_{0}$ is the distance between the pattern and the anti-pattern.

The values of development measure are within the interval $(0 ; 1)$. The higher value of the measure is interpreted as a higher level of complexity of the phenomenon and assessed as favourable in terms of view of the criterion of the purpose.

Grading into classes was carried out using the average and standard deviation.

\section{$4 \quad$ Research results}

For the purpose of efficient description of the research results, the values of synthetic indicators determined for each of the 29 examined districts of Lower Silesia in 2003-2013 were calculated, and the districts were ordered linearly according to those values. It can be mentioned that cities with district status are all characterized by the highest synthetic indicator values in comparison with the land districts. 
Tab. 2: Development measures of the Lower Silesia districts in 2003-2013

\begin{tabular}{|c|c|c|c|c|c|c|}
\hline \multirow[b]{2}{*}{ No. } & \multicolumn{2}{|l|}{2003} & \multicolumn{2}{|l|}{2008} & \multicolumn{2}{|l|}{2013} \\
\hline & $\begin{array}{c}\text { District/research } \\
\text { object }\end{array}$ & \begin{tabular}{|c|} 
Dev. \\
Measure
\end{tabular} & $\begin{array}{c}\text { District/research } \\
\text { object }\end{array}$ & $\begin{array}{c}\text { Dev. } \\
\text { Measure }\end{array}$ & $\begin{array}{c}\text { District/research } \\
\text { object }\end{array}$ & $\begin{array}{c}\text { Dev. } \\
\text { Measure }\end{array}$ \\
\hline 1 & city of Wrocław & 0.4623 & city of Wrocław & 0.4954 & city of Wrocław & 0.4976 \\
\hline 2 & Zgorzelecki & 0.3409 & city of Legnica & 0.3394 & city of Legnica & 0.2736 \\
\hline 3 & city of Legnica & 0.3368 & city of Jelenia Góra & 0.3135 & Wrocławski & 0.2490 \\
\hline 4 & city of Jelenia Góra & 0.3011 & Wrocławski & 0.3032 & Jeleniogórski & 0.2434 \\
\hline 5 & Wrocławski & 0.2048 & Jeleniogórski & 0.2185 & city of Jelenia Góra & 0.2233 \\
\hline 6 & Wałbrzyski* & 0.1932 & Lubiński & 0.1632 & Polkowicki & 0.1861 \\
\hline 7 & Jeleniogórski & 0.1831 & Wałbrzyski* & 0.1587 & Lubiński & 0.1713 \\
\hline 8 & Kłodzki & 0.1595 & Zgorzelecki & 0.1528 & Oławski & 0.1160 \\
\hline 9 & Lubiński & 0.1416 & Polkowicki & 0.1451 & Kłodzki & 0.0908 \\
\hline 10 & Kamiennogórski & 0.1367 & Kłodzki & 0.1307 & Zgorzelecki & 0.0887 \\
\hline 11 & Dzierżoniowski & 0.1320 & Dzierżoniowski & 0.1206 & Świdnicki & 0.0850 \\
\hline 12 & Świdnicki & 0.1281 & Świdnicki & 0.1160 & Głogowski & 0.0763 \\
\hline 13 & Polkowicki & 0.1186 & Ząbkowicki & 0.0925 & Wałbrzyski* & 0.0728 \\
\hline 14 & Bolesławiecki & 0.1013 & Lubański & 0.0850 & Średzki & 0.0712 \\
\hline 15 & Trzebnicki & 0.1008 & Głogowski & 0.0808 & Wołowski & 0.0649 \\
\hline 16 & Lwówecki & 0.0976 & Wołowski & 0.0785 & Ząbkowicki & 0.0554 \\
\hline 17 & Ząbkowicki & 0.0830 & Trzebnicki & 0.0779 & Dzierżoniowski & 0.0531 \\
\hline 18 & Strzeliński & 0.0809 & Bolesławiecki & 0.0715 & Trzebnicki & 0.0456 \\
\hline 19 & Lubański & 0.0772 & Oławski & 0.0681 & Złotoryjski & 0.0365 \\
\hline 20 & Oławski & 0.0703 & Lwówecki & 0.0596 & Lubański & 0.0360 \\
\hline 21 & Legnicki & 0.0623 & Kamiennogórski & 0.0526 & Bolesławiecki & 0.0331 \\
\hline 22 & Średzki & 0.0521 & Jaworski & 0.0457 & Strzeliński & 0.0301 \\
\hline 23 & Głogowski & 0.0476 & Legnicki & 0.0409 & Legnicki & 0.0273 \\
\hline 24 & Jaworski & 0.0463 & Średzki & 0.0334 & Oleśnicki & 0.0258 \\
\hline 25 & Wołowski & 0.0407 & Złotoryjski & 0.0323 & Lwówecki & 0.0238 \\
\hline 26 & Złotoryjski & 0.0353 & Górowski & 0.0320 & Jaworski & 0.0211 \\
\hline 27 & Milicki & 0.0321 & Strzeliński & 0.0267 & Kamiennogórski & 0.0131 \\
\hline 28 & Oleśnicki & 0.0311 & Oleśnicki & 0.0225 & Milicki & 0.0107 \\
\hline 29 & Górowski & 0.0000 & Milicki & 0.0000 & Górowski & 0.0000 \\
\hline
\end{tabular}

Source: Own

During the analysis of the values of the synthetic measure of development in individual districts, it can be remarked that since 2003, the city of Wrocław district had been classified by the highest synthetic indicator values. Furthermore, its synthetic indicator had been incessantly growing, which can be an evidence of continuous development in the researched dimensions and variables. The district which had similarly been at the top of the classification each year was the city of Legnica district. From the third position in 2003, it went up to the second in 2008 and it did not change its position in the last period of research. Zgorzelecki district, which had been classified on the second position in 2003 , fell to the $8^{\text {th }}$ in 2008 and $10^{\text {th }}$ in 2013. One of the many reasons can be the flood in 2010 and its social and economic after-effects. It should be marked that in the case of this district, in comparison with the base year, the synthetic indicator value had extremely decreased. The fall of the indicator value in the Zgorzelecki district is the highest from all the researched districts. The city of Jelenia Góra district, also on the top of the list in 2003, had been declining in the ranking. In 2008 this district had increased the indicator value, but in the following researched period- 2013, it finally ended at the $5^{\text {th }}$ place. However, it stayed in the group of districts characterized by the highest synthetic indicator values among all the researched objects. 
Wrocławski district (land district) had improved its position, from the $5^{\text {th }}$ in 2003 to the $3^{\text {rd }}$ in 2013 (despite the slight fall in the value of the indicator regarding to 2008). Wałbrzyski district was at the $6^{\text {th }}$ place at the first period of the research project. In 2008 and 2013, its position meaningfully worsened, putting this district finally to the $13^{\text {th }}$ place. The situation of Jeleniogórski district was opposite; its synthetic indicator values had been increasing during all researched periods, which gave it finally the $4^{\text {th }}$ place in ranking in 2013. Kłodzki district, because of the minor drop of indicator values, fell from the $8^{\text {th }}$ place in 2003 to the $9^{\text {th }}$ in 2013. Lubiński district, despite a small increase of the calculated indicator, moved from the $9^{\text {th }}$ place, occupied in 2003, to the $7^{\text {th }}$ place in 2013. In the case of Kamiennogórski district, due to changes in the value of the indicator, it shifted by eight places downwards in 2008 and by another six in 2013, which gave it the 27 th place in the ranking of districts. The value of the synthetic indicator for this district was certainly also lower in 2013 in comparison with the base year.

Dzierżoniowski district had been one of the few objects which remained on the same place in ranking in 2003 and 2008, despite of the small drop in the value of the synthetic indicator in those periods. Unfortunately, the continuing decrease shifted it from the $11^{\text {th }}$ place to the $17^{\text {th }}$ in 2013. On the other hand, Świdnicki district, which in 2003 and 2008 had been in the same situation as the Dzierżoniowski district, shifted from the $12^{\text {th }}$ place in the base year to the $11^{\text {th }}$ in 2013, despite the fact that the value of the synthetic indicator in this object also diminished.

In the case of Polkowicki district ( $13^{\text {th }}$ place in 2003), it was an object for which the highest increase of the indicator was apparent (evidently the indicator value had increased constantly). Since 2003 the Polkowicki district had become the sixth district in the ranking.

Bolesławiecki district occupied the $14^{\text {th }}$ place in 2003, the $18^{\text {th }}$ in 2008 and the 21 st in 2013. Its position among the districts of Lower Silesia significantly declined. The value of synthetic indicator fell continuously during the researched period. Trzebnicki district was in a similar situation, in 2008 , this district fell from the $15^{\text {th }}$ to the $17^{\text {th }}$ position because of the diminishing indicator value. In the following research period, 2013, the Trzebnicki district found itself at the $17^{\text {th }}$ position, experiencing again a slight decline in the indicator value. Comparable changes had been shown in the Lwówecki district. Its indicator values and, at the same time, its position in the ranking had been worsening year by year as well. The Lwowecki district shifted from the $16^{\text {th }}$ place in 2003 to the $25^{\text {th }}$ in 2013.

The Ząbkowicki district in 2003 was at the $17^{\text {th }}$ place among the districts of Lower Silesia. The highest indicator level for this district was observed in 2008 (which gave it the $13^{\text {th }}$ place). However, after this year, a decline in the calculated indicator was apparent and in 2013 its value was lower than at the beginning of the study period. In the case of the Strzeliński district, the highest indicator level was witnessed in the base year, and it fell after that placing this district by nine places downwards at the $27^{\text {th }}$ place in 2008 . In 2013 its position quite significantly improved putting this district at the $22^{\text {nd }}$ place in 2015 . Nonetheless, its indicator value at the end of the research was lower than at the beginning.

In 2008 the Lubański district had the first increase in the indicator value, but in the following research period it descreased, and the Lubański district ended at the $20^{\text {th }}$ place in the ranking. Despite the slight decline in the indicator value in 2008, the Oolawski district shifted one place upwards, and further, eleven places upwards in 2013. That shift (a positive change) in the third researched period in comparison to the second one, was the highest among all of the districts. Similar alterations were shown in the Głogowski, Wołowski, and Średzki districts. In spite of the fluctuations of indicator values in all of those districts their positions in ranking has improved significantly. 
Although the value of the indicator in the Legnicki district had been declining during all the research period, its position shifted only in 2008. In 2013 it remained at the $20^{\text {th }}$ position among all Lower Silesia districts. Despite the lower indicator value in 2008, the Jaworski district improved its position, from the $24^{\text {th }}$ to the $22^{\text {nd }}$. Unfortunately, a further decrease of the value of the synthetic indicator caused a diminishing position of that district to the $26^{\text {th }}$ in the ranking.

Albeit the increase in the indicator value in the Złotoryjski district had not been really significant, its position improved substantially giving it the $19^{\text {th }}$ place in the ranking.

The Milicki district, one of the three districts with the lowest indicator value in the base year, achieved the lowest rate of the calculated indicator in 2008 and finally was placed at the $29^{\text {th }}$ position in 2013. Despite the fact that the value of the indicator in the following years in the Oleśnicki district had been decreasing, it improved its position shifting from the $28^{\text {th }}$ to the $24^{\text {th }}$ place.

The Górowski district in 2003 was on the last position of the ranking. However, after that an increase in the value of the indicator had been noticed for this object. In 2008 it shifted its position to the $26^{\text {th }}$ place, but unfortunately the value of this indicator dropped again and the Górowski district fell to the last place in 2013.

It must be emphasised that even the smallest change in the indicator value can lead to significant alterations in the ranking of the investigated objects.

All districts of the Lower Silesia in the research period could be divided into three groups. Firstly, a group of districts for which the synthetic indicator had declined in comparison with 2006. This group included: Zgorzelecki, Kamiennogórski, Wałbrzyski, Dzierżoniowski, the city of Jelenia Góra, Lwówecki, Kłodzki, Bolesławiecki, the city of Legnica, Trzebnicki, Strzeliński, Świdnicki, Lubański, Legnicki, Ząbkowicki, Jaworski and Milicki districts. The second group (the smallest one) involved the districts for which the synthetic indicator had not undergone any major changes. Those districts were: Oleśnicki, Górowski, and Złotoryjski. The last group consisted of the districts which had improved their positions in the ranking due to the growth of the indicator. This group of districts included: Średzki, Wołowski, Głogowski, Lubiński, the city of Wrocław, Wrocławski, Oławski, Jeleniogórski and Polkowicki.

In the next part of research, the resemblance of the Lower Silesia districts under examination was determined. In the analysis, 4 groups of districts, similar to each other in each of the research periods, with regard to the examined diagnostic feature - the value of the synthetic indicator, were distinguished. As mentioned before grading into classes was carried out using the average and standard deviation. The determined groups are shown in Tab. 3.

The first group, named for the research purposes "Districts class I", initially consisted of the city of Wrocław, Zgorzelecki, the city of Legnica and the city of Jelenia Góra districts. Over the examination periods Wrocławski and Jeleniogórski districts had been included and Zgorzelecki district got excluded from this group.

The following group of objects similar to each other, with regard to the examined diagnostic feature - the value of the synthetic indicator, "Districts class II" were in the base year the Wrocławski, Wałbrzyski, Jeleniogórski, Kłodzki, Lubiński, Kamiennogórski, and Dzierżoniowki districts. As mentioned before, in the following periods under investigation, Wrocławski and Jeleniogórski districts shifted their positions to the better class. On the other hand, in 2008 Kamiennogórski and Dzierżoniowski districts worsened their places in the ranking and moved to the "Districts class III" group. In 2013 the last period of research, 
Wałbrzyski and Zgorzelecki had been excluded from the second group and Oławski district had been included in it.

The third group included at first Świdnicki, Polkowicki, Bolesławiecki, Trzebnicki, Lwówecki, Ząbkowicki, Strzeliński, Lubański, Oławski, Legnicki, Średzki, Głogowski, Jaworski, Wołowski, and Złotoryjski districts. In the following research period -2008 this group expanded by Górowski and Dzierżoniowski districts and diminished by Polkowicki district. In 2013 it was enlarged by Zgorzelecki, Wałbrzyski, Kłodzki and decreased by Oławski districts.

Tab. 3: Development measures of the Lower Silesia districts in 2003-2013 with their classification to particular groups

\begin{tabular}{|c|c|c|c|c|c|c|}
\hline \multirow[b]{2}{*}{ No. } & \multicolumn{2}{|l|}{2003} & \multicolumn{2}{|l|}{2008} & \multicolumn{2}{|l|}{2013} \\
\hline & $\begin{array}{c}\text { District/research } \\
\text { object }\end{array}$ & $\begin{array}{c}\text { Dev. } \\
\text { Measure }\end{array}$ & $\begin{array}{c}\text { District/research } \\
\text { object }\end{array}$ & $\begin{array}{c}\text { Dev. } \\
\text { Measure }\end{array}$ & $\begin{array}{c}\text { District/research } \\
\text { object }\end{array}$ & $\begin{array}{c}\text { Dev. } \\
\text { Measure }\end{array}$ \\
\hline 1 & city of Wrocław & 0.4623 & city of Wrocław & 0.4954 & city of Wrocław & 0.4976 \\
\hline 2 & Zgorzelecki & 0.3409 & city of Legnica & 0.3394 & city of Legnica & 0.2736 \\
\hline 3 & city of Legnica & 0.3368 & city of Jelenia Góra & 0.3135 & Wrocławski & 0.2490 \\
\hline 4 & city of Jelenia Góra & 0.3011 & Wrocławski & 0.3032 & Jeleniogórski & 0.2434 \\
\hline 5 & Wrocławski & 0.2048 & Jeleniogórski & 0.2185 & city of Jelenia Góra & 0.2233 \\
\hline 6 & Wałbrzyski* & 0.1932 & Lubiński & 0.1632 & Polkowicki & 0.1861 \\
\hline 7 & Jeleniogórski & 0.1831 & Wałbrzyski* & 0.1587 & Lubiński & 0.1713 \\
\hline 8 & Kłodzki & 0.1595 & Zgorzelecki & 0.1528 & Oławski & 0.1160 \\
\hline 9 & Lubiński & 0.1416 & Polkowicki & 0.1451 & Kłodzki & 0.0908 \\
\hline 10 & Kamiennogórski & 0.1367 & Kłodzki & 0.1307 & Zgorzelecki & 0.0887 \\
\hline 11 & Dzierżoniowski & 0.1320 & Dzierżoniowski & 0.1206 & Świdnicki & 0.0850 \\
\hline 12 & Świdnicki & 0.1281 & Świdnicki & 0.1160 & Głogowski & 0.0763 \\
\hline 13 & Polkowicki & 0.1186 & Ząbkowicki & 0.0925 & Wałbrzyski* & 0.0728 \\
\hline 14 & Bolesławiecki & 0.1013 & Lubański & 0.0850 & Średzki & 0.0712 \\
\hline 15 & Trzebnicki & 0.1008 & Głogowski & 0.0808 & Wołowski & 0.0649 \\
\hline 16 & Lwówecki & 0.0976 & Wołowski & 0.0785 & Ząbkowicki & 0.0554 \\
\hline 17 & Ząbkowicki & 0.0830 & Trzebnicki & 0.0779 & Dzierżoniowski & 0.0531 \\
\hline 18 & Strzeliński & 0.0809 & Bolesławiecki & 0.0715 & Trzebnicki & 0.0456 \\
\hline 19 & Lubański & 0.0772 & Oławski & 0.0681 & Złotoryjski & 0.0365 \\
\hline 20 & Oławski & 0.0703 & Lwówecki & 0.0596 & Lubański & 0.0360 \\
\hline 21 & Legnicki & 0.0623 & Kamiennogórski & 0.0526 & Bolesławiecki & 0.0331 \\
\hline 22 & Średzki & 0.0521 & Jaworski & 0.0457 & Strzeliński & 0.0301 \\
\hline 23 & Głogowski & 0.0476 & Legnicki & 0.0409 & Legnicki & 0.0273 \\
\hline 24 & Jaworski & 0.0463 & Średzki & 0.0334 & Oleśnicki & 0.0258 \\
\hline 25 & Wołowski & 0.0407 & Złotoryjski & 0.0323 & Lwówecki & 0.0238 \\
\hline 26 & Złotoryjski & 0.0353 & Górowski & 0.0320 & Jaworski & 0.0211 \\
\hline 27 & Milicki & 0.0321 & Strzeliński & 0.0267 & Kamiennogórski & 0.0131 \\
\hline 28 & Oleśnicki & 0.0311 & Oleśnicki & 0.0225 & Milicki & 0.0107 \\
\hline 29 & Górowski & 0.0000 & Milicki & 0.0000 & Górowski & 0.0000 \\
\hline
\end{tabular}

Legend:

Districts class I

Districts class II

Districts class III

Districts class IV

Source: Own

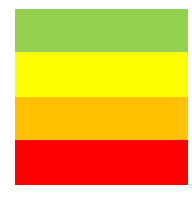

The last and the least numerous group of similar objects consisted of Górowski district in 2003 and 2013 and of Milicki dostrict in 2008. 
At the same time it should be noted that over the research periods the numerical amount of the "Districts class I" and "Districts class III" had been increased, the "Districts class II" diminished, and the "Districts class IV" stayed at the same level. The places of individual districts in the ranking, even when they stayed in the same group, have also changed.

\section{Conclusions}

The conducted analysis shows that there are significant trends in the development of individual districts of the province of Lower Silesia. The biggest degree of polarization has been observed between the "Districts class I" (including strong centers of growth and development, such as the cities of Jelenia Góra and Wrocław) and the "Districts class IV" and "Districts class III". It can be also assumed that the development of the regions surrounding the mentioned strong centres of growth will proceed. The changes in the values of the synthetic indicator over the years under examination are shown in Fig. 1 and Fig. 2.

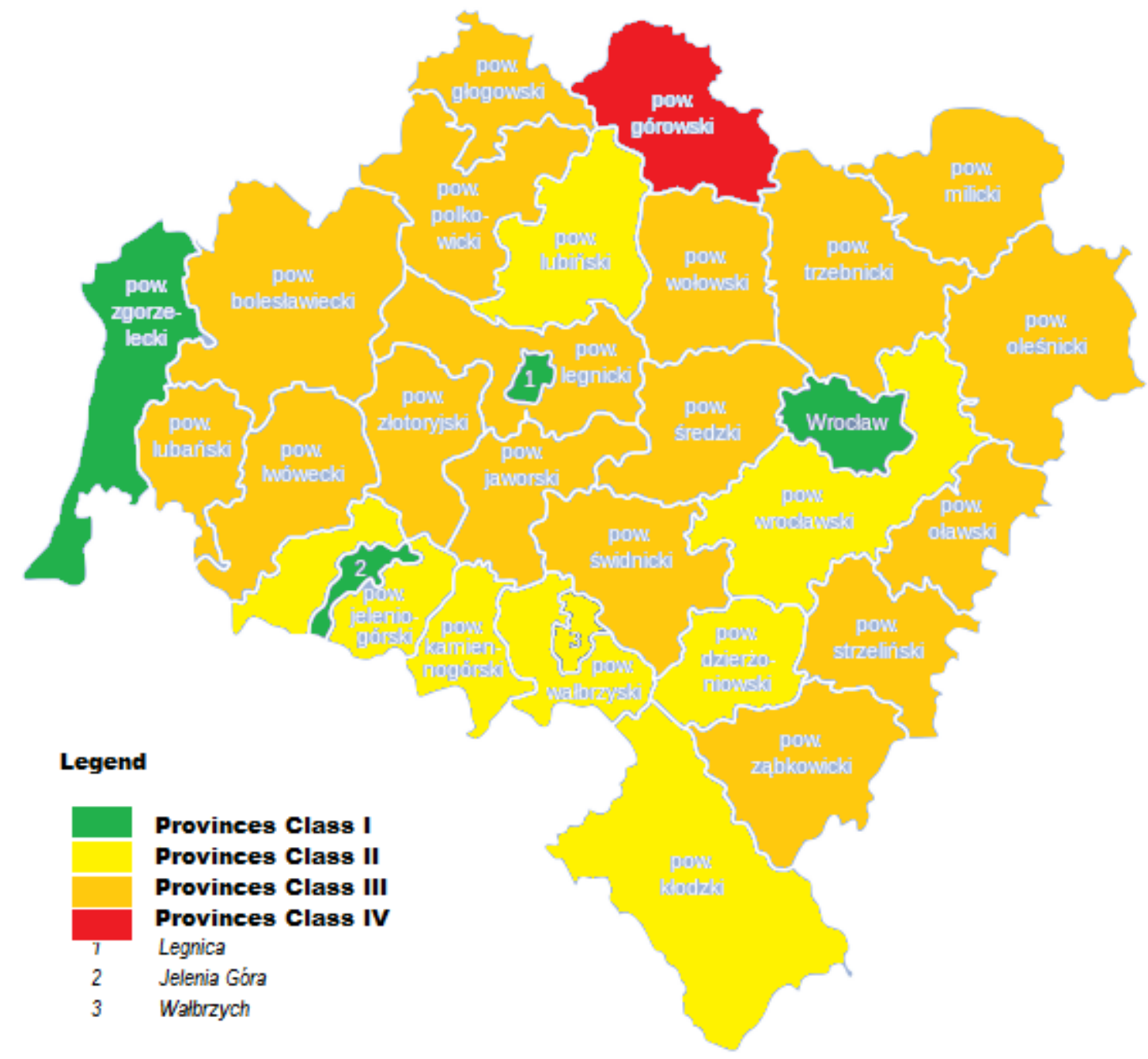

Source: Own

Fig. 1: Districts classes map in 2003

During the research period the polarization among the city of Wrocław and other centers of growth became stronger. The highest degrees of polarization were observed in 2003 and in 2013 between the city of Wrocław and Gorowski district and in 2008 between the city of Wrocław and Milicki district. In the analyzed period the polarization extent between the city of Wrocław district and Jeleniogórski, Oławski, and Polkowicki districts decreased. In the remaining districts the degree of polarization in regard to the city of Wrocław increased, the 
most in the case of Zgorzelecki district. A large polarization of the city of Wrocław also occurred in relation to Bolesławiecki, Dzierżoniowski, Kamiennogórski, and Wałbrzyski districts.

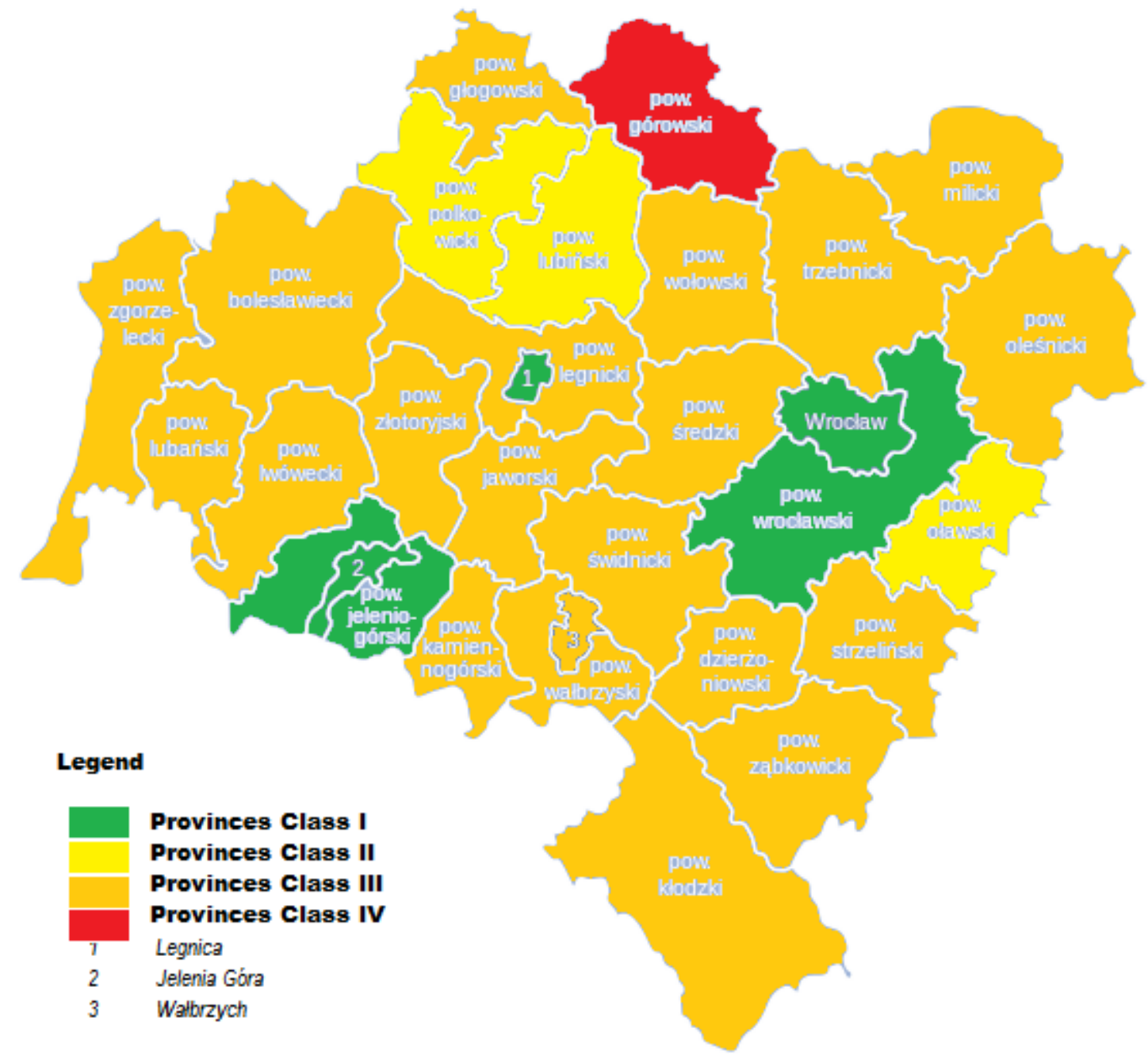

Source: Own

Fig. 2: Districts classes map in 2013

The decreasing value of the synthetic indicator in Zgorzelecki district caused its diminishing from the strong center of growth in 2003 (the 2nd position in the ranking among all districts of Lower Silesia) to the "Districts class III" and the $10^{\text {th }}$ position in 2013.

In the research period Polkowicki district experienced a significant increase in the value of the synthetic indicator, due to the development in the mining industry (KGHM Polska Miedź S.A.). Furthermore, it was one of the districts which had considerably increased their position in the ranking (an increase by 7 places, from the $13^{\text {th }}$ position in 2003 in the "Districts class III" to the $6^{\text {th }}$ position in 2013). It should be added that this was the largest increase among all districts.

Among the distinguished objects in the "Districts class I" the biggest degree of polarization had been noted between the city of Wrocław and the city of Jelenia Góra districts.

To sum up the performed analysis, it should be remarked that a decrease of development disproportions requires time, thus, in order to follow the process of changes, exploration in this area should be continued. 


\section{Literature}

[1] KANCELARIA PREZESA RADY MINISTRÓW: Polska 2030. Wyzwania rozwojowe. [online]. Poland, 2009. [accessed: 2015-05-20]. Available from WWW: https://www.mpips.gov.pl/gfx/mpips/userfiles/_public/1_NOWA\%20STRONA/Aktualn osci/seniorzy/badania\%20aktywne\%20starzenie/pl_2030_wyzwania_rozwojowe.pdf

[2] SMITH, A.: An Inquiry into the Nature and Causes of the Wealth of Nations. PWN, Warsaw, 2007. ISBN: 978-83-01-15031-0.

[3] DYJACH, K.: Theories of the regional development in view of interregional disparities. [online]. Lublin, University of Mariae Curie-Skłodowska, 2013. [accessed 22.05.2015]. Available from

WWW: http://annales.umcs.lublin.pl/tt_p.php?rok=2013\&tom=47\&sectio=H\&numer_artykulu= $\underline{03 \& z e s z y t=1}$

[4] GAWLIKOWSKA-HUECKEL, H.: Procesy rozwoju regionalnego w Unii Europejskie. Konwergencja, czy polaryzacja? Wydawnictwo Uniwersytetu Gdańskiego, Gdańsk, 2003. ISBN: 83-7326-085-4.

[5] STOHR, W.: Development from Above or Below? The Dialectics of Regional Planning in Developing Countries. University of California, Wiley, London, 1981. ISBN: 0-47127823-8.

[6] RISKIN, C.: China's political economy: the quest for development since 1949. Oxford University Press, 1987. ISBN: 0-198-77090-9.

[7] FEDOROV, L.: Regional inequality and regional polarization in Russia 1990-99. In: World development: the multi-disciplinary international journal devoted to the study and promotion of world development. Elsevier Science, 30(3), 2002. ISSN 0305-750X

[8] VANDERPUYE-ORGLE, J.: Spatial inequality and polarisation in Ghana, 1987-99. Paper presented at the Conference on Spatial Inequalities in Africa, Centre for the Study of African Economies, University of Oxford, 2002.

[9] MUSIAŁ-MALAGO, M.: Polaryzacja strukturalna Krakowskiego Obszaru Metropolitalnego. In: Prace Naukowe UE we Wroclawiu. Nr 241, pp. 120-132. Wydawnictwo UE we Wrocławiu, Wrocław, 2011. ISSN: 1899-3192.

[10] WAWRZYNIAK, K.; BATÓG, B.: Polaryzacja powiatów województwa zachodniopomorskiego według wybranych kategorii ekonomicznych. In: Studia i Prace Wydziału Nauk Ekonomicznych i Zarzadzania Uniwersytetu Szczecińskiego. Nr 36. Wydawnictwo Naukowe Uniwersytetu Szczecińskiego, Szczecin, 2014. ISSN 16406818.

[11] HIRSCHMAN, A. O.: Investment Policies and "Dualism" in Underdeveloped Countries. American Economic Review. 47, No. 5, 1957. ISSN 0002-8282.

[12] MALINA, A.: Wielowymiarowa analiza przestrzennego zróżnicowania struktury gospodarki Polski wedlug województw. Wydawnictwo AE w Krakowie, Kraków, 2004. ISBN: 978-83-7252-400-3.

[13] DZIECHCIARZ, J.: Ekonometria. Metody, przyktady, zadania. Wydawnictwo Akademii Ekonomicznej im. Oskara Langego we Wrocławiu, Wrocław, 2003. ISBN 978-83-7695-147-8. 


\section{IDENTIFIKACE STUPNĚ POLARIZACE OKRESŮ NUTS4 V DOLNOSLEZSKÉM VOJVODSTVÍ S VYUŽITÍM UKAZATELE HOSPODÁŘSKÉHO RŮSTU}

Identifikace a výzkum rozvojových disproporcí regionů má velký význam z hlediska efektivity činností prováděných $\mathrm{v}$ rámci regionální politiky. Cílem tohoto článku bylo popsat stupeň polarizace jednotlivých okresů $\mathrm{v}$ Dolnoslezském vojvodství a rozdělit tyto oblasti do skupin z hlediska úrovně rozvoje v letech 2003, 2008 a 2013. V první kapitole je prezentován přehled polarizační teorie a přehled dosavadního výzkumu. V následující kapitole jsou podrobně popsány cíle a oblasti výzkumu. Třetí kapitola je věnována metodologii výzkumu se zaměřením na syntetické ukazatele hospodářského růstu. $\mathrm{V}$ závěrečné části jsou prezentovány výsledky provedených výzkumů.

\section{Die KeNNUNG DER PolarisiERUNGSGRAD DER LANDKREISE NUTS4 IN NIEDERSCHLESIEN MIT DER BENUTZUNG DES MAßES DER WIRTSCHAFTSENTWICKLUNG}

Die Kennung und Forschung der Entwicklungs-Disproportionen ist von großer Bedeutung aus der Sicht der Effektivität des Handelns, die im Rahmen der Regionalpolitik unternommen sind. Der Zweck dieses Artikels war, den Grad der Polarisation der Landkreise in Niederschlesien und die Einteilung in Gruppen von Entwicklungsniveau in den Jahren 2003, 2008 und 2013 zu bestimmen. Im ersten Kapitel werden der Abriss der Polarisationstheorie und Überblick der bestehenden Studien geschildert. Das nächste Kapitel beschreibt detailliert die Ziele und Forschungsbereichen. Das dritte Kapitel ist der Methodologie der Forschung mit besonderem Schwerpunkt auf synthetische Maß der Wirtschaftsentwicklung gewidmet. Im letzten Abschnitt werden die Forschungsergebnisse dargestellt.

\section{IDENTYFIKACJA STOPNIA POLARYZACJI POWIATÓW NUTS4 W WOJEWÓDZTWIE DOLNOŚLĄSKIM Z WYKORZYSTANIEM MIARY ROZWOJU GOSPODARCZEGO}

Identyfikacja i badanie dysproporcji rozwojowych regionów ma duże znaczenie $\mathrm{z}$ punktu widzenia efektywności działań podejmowanych $\mathrm{w}$ ramach polityki regionalnej. Celem niniejszego artykułu było określenie stopnia polaryzacji powiatów w województwie dolnośląskim i podział ich na grupy względem poziomu rozwoju w latach 2003, 2008 i 2013. W pierwszym rozdziale zaprezentowano zarys teorii polaryzacji i przegląd dotychczasowych badań. W kolejnym rozdziale szczegółowo opisano cele i obszary badawcze. Trzeci rozdział poświęcono metodologii badań ze szczególnym uwzględnieniem syntetycznej miary rozwoju gospodarczego. W ostatniej części zaprezentowano wyniki przeprowadzonych badań. 